Article

\title{
Pre-Service Teachers' Perceptions of Emotions and Self-Regulatory Learning in Emergency Remote Learning
}

\author{
Lucas Kohnke $^{1, *}$, Di Zou ${ }^{2}$ and Ruofei Zhang ${ }^{3}$ \\ 1 English Language Centre, Faculty of Humanities, The Hong Kong Polytechnic University, Hong Kong \\ 2 Department of English Language Education, The Education University of Hong Kong, Hong Kong; \\ dzou@eduhk.hk \\ 3 Department of Mathematics and Information Technology, The Education University of Hong Kong, \\ Hong Kong; rzhang@eduhk.hk \\ * Correspondence: lucas.kohnke@polyu.edu.hk
}

Citation: Kohnke, L.; Zou, D.; Zhang, R. Pre-Service Teachers' Perceptions of Emotions and Self-Regulatory Learning in Emergency Remote Learning Sustainability 2021, 13, 7111 https://doi.org/10.3390/ su13137111

Academic Editor: Adela García-Aracil

Received: 23 April 2021

Accepted: 21 June 2021

Published: 24 June 2021

Publisher's Note: MDPI stays neutral with regard to jurisdictional claims in published maps and institutional affiliations.

Copyright: (c) 2021 by the authors. Licensee MDPI, Basel, Switzerland. This article is an open access article distributed under the terms and conditions of the Creative Commons Attribution (CC BY) license (https:// creativecommons.org/licenses/by/ $4.0 /)$.

\begin{abstract}
This study explored emotions and self-regulatory learning in postgraduate students, forced to transition to emergency remote teaching, at a Hong Kong university after the start of the academic semester. Self-regulation is a critical factor for successful online learning, and emotions are important antecedents of self-regulated learning. The study adopted a two-phase research design, with an initial online questionnaire $(n=52)$ followed by semi-structured interviews $(n=16)$ to gain a rich and holistic understanding of students' experiences. Our findings indicate that: (1) locating a suitable location to attend online classes and sharing problems with classmates were the two most frequently self-regulatory learning strategies employed by students; (2) students experienced some enjoyment attending online classes but experienced increased pressure and time commitment to complete assigned work; (3) students found online learning to lack a sense of community, making it challenging to interact with classmates. The findings suggest teachers need to incorporate various synchronous and asynchronous collaborative activities, and they need to increase their own and students' presence online to motivate and facilitate effective teaching and learning.
\end{abstract}

Keywords: COVID-19; emergency remote teaching; emotions; language learning; learning strategies; online; self-regulated learning

\section{Introduction}

As technologies have become more pervasive, the integration of online instruction into higher education has been called the "new traditional model" [1] (p. 167) or the "new normal" [2] (p. 207). It has been promoted as a key element in transforming higher education [3]. Language education in the 21st century has been influenced by the rapid advance of technology [4], and today's learners are increasingly turning to technology to master a foreign or second (L2) language [5]. With this new learning situation, online language learners must self-regulate their feelings and actions, adjust their learning efforts, and stay motivated to succeed [6,7]. Specifically, L2 learners' emotions and motivation predictors, such as frustration, boredom, and enjoyment, have direct links to their ability to succeed in this mode of learning [8-11]. Research into technologies suggests that online learning is highly demanding and that learners feel isolated, experiencing technical problems with learning management systems, computers, and Internet connections. These issues lead to undesirable achievement-related emotions, such as anxiety [12-14].

The COVID-19 pandemic forced higher education institutions to suspend face-to-face teaching and adopt fully online instruction modes, known as emergency remote teaching (ERT), to minimise physical contact [15]. Unlike online or blended learning courses designed explicitly for synchronous and asynchronous learning, ERT courses were forced to rapidly modify their course content for fully online instruction due to emergency situations [15]. ERT has presented new challenges for both teachers and learners prepared for 
courses designed for online, blended, or face-to-face classes. Hong Kong higher education, the context of the current study, has adopted various modes of synchronous and asynchronous online learning in recent years [6]. Thus, face-to-face courses are supplemented by asynchronous course material, but the adoption of ERT remains new. Considering that ERT is implemented for the first time among Hong Kong students, and they have not been trained previously for this situation, it is likely that they would experience various emotions, encounter a range of difficulties, and apply diverse strategies. However, little investigation has been conducted from these perspectives, and thus, it is necessary to examine the students' learning experiences, in terms of their emotions and difficulties, and apply diverse learning strategies during the emergency remote teaching and learning.

Moreover, despite the rapid growth in the online learning rate, very little is known about L2 students' self-regulated learning when they are forced to use online learning after starting a traditional, face-to-face course. This paper, therefore, aims to report on the findings of a mixed-method study that explores students' emotions, perceived difficulties, and learning strategies in response to the current state of forced online teaching and learning. It extends the limited literature in this area and proposes implications for promoting self-regulatory learning for online synchronous courses in higher education. These were the research questions that guided our study:

1. What emotions did students experience during emergency remote learning?

2. What difficulties did students encounter during emergency remote learning?

3. What learning strategies did students apply during emergency remote learning?

\section{Literature Review}

Although various studies have extensively examined blended learning and online learning in higher education [16-18], the recently forced adoption of online synchronous course delivery represents a new trend. Few studies to date have examined higher education L2 students' emotional states and self-regulated learning (SRL) capabilities in response to emergency remote learning.

\subsection{Learner Emotions in the Online Environment}

Emotions are subjective, complex, and difficult to grasp, but they are fundamental in facilitating effective teaching and learning [19-21]. In 2002, a seminal study [9] identified several discrete emotions relating to academics (e.g., enjoyment, hope, pride, anxiety, shame, anger, boredom, hopelessness). Later on, Pekrun and others [22,23] proposed the control-value theory, which has been tested in multiple face-to-face and online learning environments $[24,25]$. The results support the view that academic emotion is integral to understanding motivations, learning strategies, and performance.

Research on academic emotions and online learning has identified frustration, confusion, anxiety, isolation [26], enjoyment, confidence, and fear [27] as the predominant feelings that learners experience. As far as the relationship between emotions and SRL, [28] boredom and fear have not been found to markedly affect SRL. Enjoyment, however, fosters it. Notably, emotions have received relatively little attention in the L2 literature [29-31], which is surprising given L2 learning encompassing a wide variety of emotions, including joy, gratification, anxiety, and boredom [32]. It is now important to further investigate student perceptions of the forced adoption of online learning and how it influences students' emotions and SRL.

\subsection{Learning Difficulties in the Online Environment}

Online SRL is not always successful, and studies have identified various difficulties students may encounter therein. For example, many students may find it challenging to determine the appropriate time and place for virtual learning [33]. As a result of these difficulties, learners tend to suffer from high levels of anxiety and frustration [33], procrastinate, and experience low motivation in online SRL [34]. Additionally, researchers identified a strong sense of isolation and discomfort commonly experienced by students in 
SRL, which may negatively influence learner motivation and efficiency [35]. Moreover, as the majority of students have been accustomed to the teacher-centred, face-to-face learning approach, they have often lacked awareness of, and skill, in planning and managing study on their own [36].

Although many researchers have identified difficulties in online learning, SRL, and the resulting impacts on student efficiency and performance, studies focusing on this issue remain few. To obtain a better understanding of this learning approach, it may be valuable to investigate learners' perceived difficulties in the online environment.

\subsection{Self-Regulated Language Learning Strategies in the Online Environment}

Many SRL theories have been conceptualised in the last several years. One comprehensive review [37] found them to generally represent learning as a recurring process involving three distinct features: forethought, which includes goal-setting and strategic planning; performance or volition, which emphasises strategies in focus and self-monitoring; selfreflection as to how the learner has reacted to earlier learning processes and set future goals. Research has also established that self-regulatory learners are more active learners [38], seek help from instructors and classmates [39], generally manage their efforts and complete tasks with better results [40,41], and have high confidence in their learning [42]. On the other hand, less self-regulated learners have low confidence, show poor goal-setting, and fault teachers or course design for unsatisfactory performance [43]. Further research by [43] (p. 11) established that "self-regulated learners have four key qualities: intrinsic goal orientation, high confidence in learning, high control of learning beliefs, and high task value." In online course delivery, there is a strong correlation between self-regulated learning and achievement, persistence, and satisfaction [40,44]. Successful online learners are proactive, take initiative in online discussions, complete tasks on time, and regularly review course materials [45]. Intimately interlaced with learner autonomy, SRL is essential for learner success [46] and - as the review above shows—is a salient element for describing online learning experiences. More thorough research may contribute to pedagogical knowledge of how to deliver online learning.

In L2 education, an increasing number of researchers have established that selfregulated learners tend to have better language learning outcomes [47]. Research into technology-enhanced language learning has particularly illuminated the factors contributing to L2 learners' SRL and the benefits of SRL to L2 learning. Studies exploring Chinese EFL students' online SRL note the positive impact of technology for authentic communication, helping learners become more informed about the target language and culture and placing a higher value on memorisation [48]. In another study, [6] explored Hong Kong students' technology use outside the classroom and its influence on self-regulation in L2 learning. Their findings indicated that technology helps learners access learning resources, creates a more authentic learning experience, and sustains student learning goals. These findings echo a recent study by [49], in which SRL played an essential role in a successful language learning experience. However, while several positive attributes have emerged - as discussed above-less encouraging findings, such as [50] in their study of Turkish learners, have suggested that technology hampers communication and interaction between L2 learners.

Previous research has established that quality is the most important factor in satisfaction regarding online interactions between instructor-student, student-peer, and studentcontent [51]. Similarly, studies have found that teachers can increase their closeness with students by incorporating verbal, or non-verbal, behaviours that reduce the perceived distance [52], creating a sense of community and helping students perform better academically $[53,54]$. Consequently, investigating how teachers communicate and interact with students online-as well as how students communicate, and interact online, with each other-is especially relevant, as is the role of communication in SRL. This information may contribute to and inform curriculum design, online instruction, and theory. 


\section{Methods}

\subsection{Setting and Participants}

The university studied is one of eight publicly funded universities in Hong Kong, and it offers undergraduate and postgraduate programmes. We applied convenience sampling in this study. The elective credit-bearing course of the Master of Education programme consists of 13 weekly three-hour, face-to-face modules offered to postgraduate students. Participants originated from Mainland China and spoke Mandarin as a first language with English as an L2. As such, they were culturally and linguistically homogenous. The participants, who volunteered for the study, ranged from 21 to 34 years old-34 female and 18 male - and were proficient in everyday technologies (e.g., mobile phones, tablets, social media). Though from different academic disciplines, they shared similar educational backgrounds. All participants had completed undergraduate study and were pursuing a master's degree during this research. The study was conducted while strictly following the research ethics of the university.

The first three weeks of the course in question were taught face-to-face. Students used Moodle as their course management platform with additional blended learning resources (e.g., videos, articles, podcasts, discussion forums, websites, and tech tools [Padlet, Lino]). As COVID-19 spread, all face-to-face courses were suspended, and participants returned to Mainland China. This led to the adoption of ERT delivery and necessitated students to attend synchronous classroom instruction for the remainder of the academic semester. Zoom (https: / / zoom.us / accessed on 24 June 2021) was chosen as the delivery platform for the synchronous sessions because of its lack of being censored in Mainland China, its high compatibility with different devices and operating systems [55], and its accessibility for both experienced and inexperienced users [56]. Earlier studies found Zoom to facilitate active language learning activities, reduce anxiety, and promote participation and meaningful language production $[57,58]$.

\subsection{Data Collection and Analysis}

The participants' experiences with Zoom-supported online teaching and its effects on their emotions and self-regulated learning strategies were collected through a mixedmethod approach, collecting two types of data in two distinct phases. In the first phase, an online questionnaire $(n=52)$ adapted from [59] a questionnaire about learner attitudes and motivation was administered to all students in the course to provide a general overview of their experiences and inform the second phase of data collection. The second phase consisted of semi-structured interviews $(n=16)$ [60]. There were a total of 36 survey questions falling into four parts: (1) participant demographics; (2) students' emotions in remote learning (e.g., "How motivated are you to attend classes remotely?"); (3) students' perceived difficulties in remote learning (e.g., "How difficult do you feel in peer-topeer interaction in remote learning?"; (4) learning strategies students applied in remote learning (e.g., "How frequently have you sought peer evaluations of your performance in online classes?"). The questionnaire employed multiple-choice questions and a 5-point Likert-type scale with response options ranging from 1 (low) to 5 (high). Analysis was done descriptively.

In the second phase, the authors conducted in-depth, semi-structured interviews with individual participants who had volunteered to participate in the questionnaire. The interviews ranged from 26 and $41 \mathrm{~min}$ and were conducted in English. Interviews utilised Zoom to minimise face-to-face contact and were audio-recorded to be later transcribed, allowing the authors to unpack the participants' statements in a more fluid manner [61,62]. Themes were identified and evaluated using iterative thematic analysis [63]. The authors performed the coding independently by hand to allow for intimate knowledge of the data. Throughout this process, the three authors maintained closed communication and shared, compared, and discussed the analyses [64] before labelling themes and subthemes. To increase the reliability of the qualitative data, a code-recode strategy [65] was employed. After the completion of the first round of 
coding, the authors waited for two weeks and then re-coded the same data. The results generated were indistinguishable from the first coding, demonstrating the findings as dependable. Each participant was provided with themes and representative quotes, and no suggestions were offered in response. The results were combined and compared with the questionnaire responses to gain rich and holistic insight $[61,66]$. The broad questions of the interviews included the following:

- "What's difficult about online learning?"

- "How do you participate/interact actively in an online class?"

- "Does online learning require more mental effort?"

- "How do you plan for your online lessons?"

- "Do you do anything different in your online studies compared with your previous face-to-face classes?"

The interviewees were coded as S1-S16.

All students participated in the questionnaire survey and interview voluntarily and had the right to withdraw at any time without penalty of any kind.

\section{Results}

\subsection{Students' Emotions during Emergency Remote Teaching and Learning}

This section presents the questionnaire and interview results concerning students ${ }^{\prime}$ emotions in response to the transition to online learning. Table 1 shows the results relating to students' emotions during online learning regarding their motivation, stress, fatigue, confidence, loneliness, and enjoyment, along with their willingness to participate in further online learning.

Table 1. Students' emotions during online learning.

\begin{tabular}{|c|c|c|c|c|c|c|c|c|c|c|}
\hline \multirow{2}{*}{ Students' Emotions } & \multicolumn{2}{|c|}{ Very Strong } & \multicolumn{2}{|c|}{ Somewhat Strong } & \multicolumn{2}{|c|}{ Neutral } & \multicolumn{2}{|c|}{ Somewhat Weak } & \multicolumn{2}{|c|}{ Very Weak } \\
\hline & $N$ & Pct. & $N$ & Pct. & $N$ & Pct. & $N$ & Pct. & $N$ & Pct. \\
\hline Motivation & 5 & $10 \%$ & 28 & $54 \%$ & 8 & $15 \%$ & 11 & $21 \%$ & 0 & $0 \%$ \\
\hline Stress & 20 & $38 \%$ & 22 & $42 \%$ & 8 & $15 \%$ & 2 & $4 \%$ & 0 & $0 \%$ \\
\hline Tiredness & 20 & $38 \%$ & 16 & $31 \%$ & 9 & $17 \%$ & 6 & $12 \%$ & 1 & $2 \%$ \\
\hline Confidence & 2 & $4 \%$ & 9 & $17 \%$ & 14 & $27 \%$ & 16 & $31 \%$ & 11 & $21 \%$ \\
\hline Loneliness & 8 & $15 \%$ & 16 & $31 \%$ & 9 & $17 \%$ & 13 & $25 \%$ & 6 & $12 \%$ \\
\hline Enjoyment & 8 & $15 \%$ & 21 & $40 \%$ & 8 & $15 \%$ & 15 & $29 \%$ & 0 & $0 \%$ \\
\hline $\begin{array}{l}\text { Willingness of having more } \\
\text { online learning courses }\end{array}$ & 4 & $8 \%$ & 12 & $23 \%$ & 9 & $17 \%$ & 24 & $46 \%$ & 3 & $6 \%$ \\
\hline
\end{tabular}

The above results suggest that overall, students who participated in online learning experienced mixed emotions. On one hand, most participants felt motivation (with 28 participants feeling somewhat motivated and 5 participants feeling very motivated) and enjoyment during the online course (with 21 participants feeling it was somewhat enjoyable and 8 participants feeling it was very enjoyable). On the other hand, they recalled the pressure (with 22 participants feeling somewhat stressed and 20 participants feeling very stressed), fatigue (with 16 participants feeling somewhat tired and 20 participants feeling very tired), loneliness (with 16 participants feeling somewhat lonely and 8 participants feeling very lonely), and lack of confidence they felt (with 16 participants feeling somewhat unconfident and 11 participants feeling very unconfident) and expressed a reluctance to take part in online learning in the future (with 24 participants feeling somewhat unwilling and 3 participants feeling totally unwilling). 
Desire and determination. Data garnered from participant interviews illustrated student emotions during online learning. It is unsurprising students were determined to participate in online learning: the course was an elective and participants were interested in expanding their knowledge of the professional practice of English Academic Purposes (EAP) teachers in China. For example, S2 said she "signed up for this course [because] I want to teach EAP in the future." S7 similarly attributed her enrolment in the course to a desire to better understand the nuances of academic English. That being said, she also mentioned that her motivation decreased when the course moved to an online format, saying, "I don't think I can learn as well online."

Confidence and uncertainty. Several participants expressed an initial lack of confidence in online learning. Upon further discussion, S7 stated that "learning online is not the same ... [it's] not as much fun, and I don't enjoy it as much." While both S1 and S12 mentioned enjoying the course overall and learning from it, they did not feel this as strongly in the online mode and experienced a sense of loneliness at times-a common thread in the interview and consistent with previous research $[67,68]$. Participants further elaborated that, during the first three weeks of classes, which they attended face-to-face, they felt more energetic and motivated to study. However, after the transition, they experienced uncertainty and self-doubt regarding their studies, and their academic results created feelings of stress and fatigue for several [69]. S5, for instance, commented that he was unable to sleep as well due to his worries about the new mode of learning. Likewise, S14 explained that earning her master's degree was "already stressful." She was unhappy about the lack of ability to interact with classmates and study on campus.

Satisfaction. Although several negative sentiments were discussed regarding online learning transition, two participants expressed feeling more comfortable interacting and participating in online learning. S16 thought this mode provided "more opportunities" and S1 expressed "strong satisfaction" with and "enjoyed" online learning, mentioning it being easier to share ideas using features on Zoom (see [57]). Ultimately, most participants felt online courses were not conducive to positive learning experiences and would be hesitant to participate in them in the future.

\subsection{Students' Perceived Difficulties with Emergency Remote Teaching and Learning}

This sub-section presents the significant difficulties faced by students during online learning, including self-regulation, using technology, concentrating on learning, interacting with peers, interacting with teachers, engaging in practical demonstrations, catching up on content, participating in activities, and transferring the knowledge and skills learned in one learning session to others or finding their relevant application. Table 2 presents the participants' various perceived difficulties.

From students' perspectives, the most significant challenges throughout online learning were self-regulation (with 31 participants feeling somewhat difficult and 13 participants feeling very difficult) and practical demonstrations (with 18 participants feeling somewhat difficult and 20 participants feeling very difficult). These two leading challenges were followed by the difficulty of interacting with peers (with 29 participants feeling somewhat difficult and 3 participants feeling very difficult), participating in activities (with 27 participants feeling somewhat difficult and 6 participants feeling very difficult), and catching up on content (with 27 participants feeling somewhat difficult and 6 participants feeling very difficult). Meanwhile, the relative difficulty of teacher-student interactions and the use of technology during online learning appeared largely acceptable for students. 
Table 2. Students' perceived difficulties with online learning.

\begin{tabular}{|c|c|c|c|c|c|c|c|c|c|c|}
\hline \multirow{2}{*}{ Students' Perceived Difficulties } & \multicolumn{2}{|c|}{ Very Strong } & \multicolumn{2}{|c|}{ Somewhat Strong } & \multicolumn{2}{|c|}{ Neutral } & \multicolumn{2}{|c|}{ Somewhat Weak } & \multicolumn{2}{|c|}{ Very Weak } \\
\hline & $N$ & Pct. & $N$ & Pct. & $N$ & Pct. & $N$ & Pct. & $N$ & Pct. \\
\hline Perceived difficulty in self-regulation & 13 & $25 \%$ & 31 & $60 \%$ & 1 & $2 \%$ & 3 & $6 \%$ & 4 & $8 \%$ \\
\hline $\begin{array}{l}\text { Perceived difficulty in } \\
\text { using technologies }\end{array}$ & 6 & $12 \%$ & 15 & $29 \%$ & 8 & $15 \%$ & 18 & $35 \%$ & 5 & $10 \%$ \\
\hline Perceived difficulty in concentration & 6 & $12 \%$ & 26 & $50 \%$ & 6 & $12 \%$ & 12 & $23 \%$ & 2 & $4 \%$ \\
\hline $\begin{array}{l}\text { Perceived difficulty in } \\
\text { peer-to-peer interaction }\end{array}$ & 3 & $6 \%$ & 29 & $56 \%$ & 9 & $17 \%$ & 9 & $17 \%$ & 2 & $4 \%$ \\
\hline $\begin{array}{l}\text { Perceived difficulty in } \\
\text { teacher-student interaction }\end{array}$ & 5 & $10 \%$ & 11 & $21 \%$ & 8 & $15 \%$ & 27 & $52 \%$ & 1 & $2 \%$ \\
\hline $\begin{array}{l}\text { Perceived difficulty in } \\
\text { practical demonstrations }\end{array}$ & 20 & $38 \%$ & 18 & $35 \%$ & 9 & $17 \%$ & 4 & $8 \%$ & 1 & $2 \%$ \\
\hline $\begin{array}{l}\text { Perceived difficulty in catching up the } \\
\text { teaching and learning content }\end{array}$ & 6 & $12 \%$ & 27 & $52 \%$ & 6 & $12 \%$ & 13 & $25 \%$ & 0 & $0 \%$ \\
\hline $\begin{array}{l}\text { Perceived difficulty in participating in } \\
\text { the teaching and learning activities }\end{array}$ & 6 & $12 \%$ & 27 & $52 \%$ & 8 & $15 \%$ & 11 & $21 \%$ & 0 & $0 \%$ \\
\hline $\begin{array}{l}\text { Perceived difficulty in connecting the } \\
\text { notes and associating different } \\
\text { teaching and learning sessions }\end{array}$ & 6 & $12 \%$ & 24 & $46 \%$ & 10 & $19 \%$ & 12 & $23 \%$ & 0 & $0 \%$ \\
\hline
\end{tabular}

\subsubsection{Uneasiness and Inexperience with Online Learning}

Lack of interaction. More information about the difficulties students faced in online learning became clear over the course of the interviews. Nine of the participants brought up a lack of interaction - not only with each other but also between student and teacher-and, at times, a resulting lack of community [59]. Students expressed that an unwillingness to turn on their video cameras or use the microphone were the main reasons behind this lack of interaction, as illustrated by S4, who stated, "Most of us don't turn on the camera. We just type in the chat, so we don't really see each other." In a similar vein, S12 added: "It's like we are strangers." When asked why they did not then turn on their cameras themselves, both S4 and S12 said they felt uncomfortable with this and found it strange to see themselves on-screen. This feeling is likely because-as no participants held previous experience with fully online courses-students were unable to psychologically prepare themselves for ERT [70].

Inexperience with technology. Participants also shared clear dissatisfaction regarding the efficiency and efficacy of online learning. This might be ascribable to students' lack of experience with the platform(s) used. Though they appreciated being able to continue attending class after the suspension of face-to-face learning, five of the participants mentioned not being overly familiar with technology and the various applications they were asked to use for the course. S7 commented, "We have Zoom, Mentimeter, Lino and something else [ ... ], and I have never used them before." Other examples of barriers provided by technology were illustrated when S12 noted needing to purchase a new laptop to participate in the lessons, and S15 brought up asking her parents to invest in faster internet bandwidth for the purpose of online study. A lack of complete student access to up-to-date computer hardware and high-bandwidth internet connections are, indeed, critical challenges to the success of online coursework.

\subsubsection{Increased Workload and Concentration}

Online learning-increased workload. Moreover, interviewees suggested that online learning increased the difficulty of remaining up to date with their work. They had to read numerous emails, access the learning management system, locate the assigned tasks, and post the tasks online once completed. S11 mentioned feeling "there is so much more information now; we have to read more emails, and the teacher assigns more tasks." When asked to elaborate, she named both discussion forums and blogs. Participants also 
expressed exhaustion from the workload, as S4 highlighted by saying, "I feel like I have to study harder" and that online learning "requires a lot more time." Similar concerns were voiced by most students who perceived online learning as more time-consuming [61,71].

Concentration level. Additionally, eight participants said that online learning required a higher degree of concentration and a more detailed approach to organisation than they had experienced previously. S7, for instance, found focusing for three hours difficult. S11 added that screen fatigue was problematic. These factors made online classes more academically challenging than those taken face-to-face.

\subsubsection{Study Environment, Opportunities and "Forced" Interactions}

Study location. Another barrier to participation in online classes experienced by those interviewed was the challenge of finding a suitable physical environment in which to study. S8 mentioned the difficulty of focusing and finding a suitable place to study, and participants shared that their parents and siblings were often also working or attending classes from home, creating a challenge in finding a quiet place to attend class.

Knowledge sharing. While online learning was perceived to create a stressful increase in workload, several students found it presented new opportunities for learning from each other. S2, for instance, experienced an increase in knowledge through reading peer responses to discussion forum-based questions. S12 further noted regarding other students sharing their ideas on the virtual whiteboard, "I can see what everyone thinks, instead of only my classmates I'm sitting next to." Thus, some participants appreciated how the virtual pedagogical tools facilitated collaboration and interaction, giving them opportunities to be more actively involved [57,72,73].

Initiative. Another frequent comment was that it was "not easy to follow the class online" (S8) or "not easy to interact with classmates" (S13). This feeling brought on a sense of confusion relating to participation and personal preparation for micro-teaching. The majority of the participants expressed similar sentiments. Moreover, the pressure to interact online, especially in breakout groups, was, in S10's words, a "headache". S11, who referred to herself as shy, said she felt "like I have to speak, so there is no silence." This feeling of forced interaction can lead to anxiety and a lack of confidence that often detracts from a learning experience. Most of those interviewed revealed that online learning required them to take more initiative in an environment they were not comfortable in. and their willingness to participate and complete tasks diminished as a result.

\subsection{Students' Self-Regulated Learning Strategies in the Emergency Remote Teaching Context}

This study identified various self-regulated learning strategies that students adopted to master the art of online learning. As shown in Table 3, selecting an appropriate location for online learning was the self-regulated learning strategy most employed by students (frequently applied by $52 \%$ of students). The second most popular self-regulated learning strategy was selecting an appropriate time for online learning (frequently applied by $31 \%$ of students). Other self-regulated learning strategies indicated by over $20 \%$ of students as frequently used were: trying to take thorough notes to summarise their learning (25\%), sharing problems with classmates online (21\%), seeking help from the instructor over email (21\%), and communicating with classmates to find out the differences between what they were learning and what their classmates were learning $(21 \%)$. The commonality of all students utilising various strategies, many of which they emphasised were not required for face-to-face classes, made it clear that the online format is a more taxing one, requiring a great deal more time and effort for students to feel comfortable and successful.

Table 4 displays further self-regulated learning strategies that students used in online learning, including:

- Allocating extra study time;

- $\quad$ Setting self-imposed standards for assignments;

- Setting short-term as well as long-term goals;

- $\quad$ Preparing questions before joining the chat room and discussion; 
- Scheduling the time for online classes and observing the schedule;

- Reading aloud the instructional materials that were posted online;

- Finding someone to consult who was knowledgeable in the course content;

- Seeking peer evaluations of their performance in online classes;

- Meeting their classmates face-to-face when needed;

- Working on extra problems beyond the assigned ones to master the course content.

Table 3. Self-regulated learning strategies that students frequently used in online learning.

\begin{tabular}{|c|c|c|c|c|c|c|c|c|c|c|}
\hline \multirow{2}{*}{$\begin{array}{l}\text { Students' Self-Regulated } \\
\text { Learning Strategies }\end{array}$} & \multicolumn{2}{|c|}{ Very Frequently } & \multicolumn{2}{|c|}{ Somewhat Frequently } & \multicolumn{2}{|c|}{ Neutral } & \multicolumn{2}{|c|}{ Somewhat Rarely } & \multicolumn{2}{|c|}{ Very Rarely } \\
\hline & $N$ & Pct. & $N$ & Pct. & $N$ & Pct. & $N$ & Pct. & $N$ & Pct. \\
\hline $\begin{array}{l}\text { Selecting an appropriate } \\
\text { location for online learning }\end{array}$ & 27 & $52 \%$ & 17 & $33 \%$ & 6 & $12 \%$ & 2 & $4 \%$ & 0 & $0 \%$ \\
\hline $\begin{array}{l}\text { Selecting an appropriate time } \\
\text { for online learning }\end{array}$ & 16 & $31 \%$ & 19 & $37 \%$ & 7 & $13 \%$ & 10 & $19 \%$ & 0 & $0 \%$ \\
\hline $\begin{array}{l}\text { Trying to take thorough notes } \\
\text { to summarise learning }\end{array}$ & 13 & $25 \%$ & 19 & $37 \%$ & 10 & $19 \%$ & 10 & $19 \%$ & 0 & $0 \%$ \\
\hline $\begin{array}{l}\text { Sharing problems with } \\
\text { classmate online }\end{array}$ & 11 & $21 \%$ & 33 & $63 \%$ & 2 & $4 \%$ & 3 & $6 \%$ & 3 & $6 \%$ \\
\hline $\begin{array}{l}\text { Seeking help from the } \\
\text { instructor over email }\end{array}$ & 11 & $21 \%$ & 32 & $62 \%$ & 6 & $12 \%$ & 3 & $6 \%$ & 0 & $0 \%$ \\
\hline $\begin{array}{l}\text { Communicating with } \\
\text { classmates to find out the } \\
\text { differences between what they } \\
\text { were learning and what their } \\
\text { classmates were learning }\end{array}$ & 11 & $21 \%$ & 25 & $48 \%$ & 5 & $10 \%$ & 9 & $17 \%$ & 2 & $4 \%$ \\
\hline
\end{tabular}

Table 4. Further self-regulated learning strategies students used in online learning.

\begin{tabular}{|c|c|c|c|c|c|c|c|c|c|c|}
\hline \multirow{2}{*}{$\begin{array}{l}\text { Students' Self-Regulated } \\
\text { Learning Strategies }\end{array}$} & \multicolumn{2}{|c|}{ Very Frequently } & \multicolumn{2}{|c|}{ Somewhat Frequently } & \multicolumn{2}{|c|}{ Neutral } & \multicolumn{2}{|c|}{ Somewhat Rarely } & \multicolumn{2}{|c|}{ Very Rarely } \\
\hline & $N$ & Pct. & $N$ & Pct. & $N$ & Pct. & $N$ & Pct. & $N$ & Pct. \\
\hline Allocating extra study time & 9 & $17 \%$ & 31 & $60 \%$ & 6 & $12 \%$ & 5 & $10 \%$ & 1 & $2 \%$ \\
\hline $\begin{array}{l}\text { Setting self-imposed standards } \\
\text { for assignments }\end{array}$ & 8 & $15 \%$ & 12 & $23 \%$ & 6 & $12 \%$ & 6 & $12 \%$ & 0 & $0 \%$ \\
\hline $\begin{array}{l}\text { Setting short-term as well as } \\
\text { long-term goals }\end{array}$ & 8 & $15 \%$ & 33 & $63 \%$ & 3 & $6 \%$ & 3 & $6 \%$ & 0 & $0 \%$ \\
\hline $\begin{array}{l}\text { Preparing questions before } \\
\text { joining in the chat room } \\
\text { and discussion }\end{array}$ & 8 & $15 \%$ & 18 & $35 \%$ & 10 & $19 \%$ & 14 & $27 \%$ & 2 & $4 \%$ \\
\hline $\begin{array}{l}\text { Scheduling the times for online } \\
\text { classes and observing } \\
\text { the schedule }\end{array}$ & 6 & $12 \%$ & 30 & $58 \%$ & 8 & $15 \%$ & 6 & $12 \%$ & 2 & $4 \%$ \\
\hline $\begin{array}{l}\text { Reading aloud the } \\
\text { instructional materials that } \\
\text { were posted online }\end{array}$ & 6 & $12 \%$ & 16 & $31 \%$ & 5 & $10 \%$ & 20 & $38 \%$ & 5 & $10 \%$ \\
\hline $\begin{array}{c}\text { Finding someone to consult } \\
\text { who was knowledgeable in the } \\
\text { course content }\end{array}$ & 6 & $12 \%$ & 31 & $60 \%$ & 3 & $6 \%$ & 10 & $19 \%$ & 2 & $4 \%$ \\
\hline $\begin{array}{l}\text { Seeking peer evaluations of } \\
\text { their performance in } \\
\text { online classes }\end{array}$ & 6 & $12 \%$ & 31 & $60 \%$ & 5 & $10 \%$ & 8 & $15 \%$ & 2 & $4 \%$ \\
\hline $\begin{array}{l}\text { Meeting their classmates } \\
\text { face-to-face when needed }\end{array}$ & 5 & $10 \%$ & 21 & $40 \%$ & 6 & $12 \%$ & 14 & $27 \%$ & 6 & $12 \%$ \\
\hline $\begin{array}{l}\text { Working on extra problems } \\
\text { beyond the assigned ones to } \\
\text { master the course content }\end{array}$ & 3 & $6 \%$ & 30 & $58 \%$ & 9 & $17 \%$ & 10 & $19 \%$ & 3 & $6 \%$ \\
\hline
\end{tabular}


Self-regulated learning Strategies. Interview data held consistent with the questionnaire results above, with all interviewees mentioning employing similar strategies in their ERT experience. The majority noted seeking instructor assistance in successfully completing assignments and tasks more frequently than they would in face-to-face classes, due to online learning's inherent uncertainties. This feedback is consistent with the findings of [39]. Participants also delegated more time to completing their assignments in this context-as S5 noted, "things just take a lot more time online." More specifically, S9 added, "I need to complete extra tasks to learn the content better and write down things I can ask during the lesson." Several students highlighted this self-regulated learning strategy, being proactive in their learning by writing down possible questions before class, in preparation for the live sessions $[43,45]$. When asked why this was important, S1 said, “The teacher can't see my paying attention otherwise." S14 likewise commented, "In the classroom, the teacher can see me, you know ... eye contact. Now I must think of a way for him to notice me." This notion of being invisible in the online classroom frustrated students and led to a fear of appearing "not to do the work" (S1).

Planning. The interviews also brought to the forefront students' need to set both short- and long-term goals as a self-regulated learning strategy to ensure they did not fall behind [37]. For example, S12 said, "It is easy to forget something now." There were 14 participants who mentioned the need to set specific goals and schedule a specific time to prepare and review for lessons. One participant, S7, said, "I write down what I need to do every week so I can be ready." Likewise, S16 related, "I have to try hard to make goals." When asked to elaborate, S16 shared, "You know, how I can study for the assignment, what I should do to get a high grade." Another student, S14, echoed this assessment of the need to set goals: "Now I need to plan carefully, so I don't fall behind." The interviews confirmed, overall, that online coursework required students to take the initiative to self-regulate their learning to succeed in their studies.

Lack of interest. Two participants in particular, S5 and S14, expressed frustration and blamed the online learning model for their submitting assignments late and falling behind on coursework. S5 said that "online learning is boring" and S14 added, "It was far from fun, [ ... ] too much energy and effort." These students found they could not motivate themselves to do what they perceived as additional work to receive an acceptable grade.

\section{Conclusions}

It is likely that ERT will continue to be the new normal in higher education for the foreseeable future. This study examined a group of university students forced to switch to online learning three weeks into the academic semester. The situation generated both positive and negative emotions. Most of the students indicated that they felt motivated: they were eager to improve their academic English skills and determined to participate in online learning. Almost as many reported that they enjoyed the online classes. A few even felt that they received more opportunities to interact online than in the physical classroom. However, the students also reported stress, fatigue, and loneliness, as well as a lack of confidence, in ERT-in some cases, because of their inexperience with it. This led to uncertainty, self-doubt, and concern about grades.

Difficulties, especially in self-regulation, experienced during ERT included finding a time and place to study, taking notes and reaching out to classmates and instructors to obtain and share knowledge. Many of the students mentioned feeling isolated because they were alone before, during, and after class. They were also uncomfortable being forced to interact online and seeing themselves on camera. The need to take the initiative to communicate with the teacher and other students, to ensure that they understood what was being taught, increased their sense of stress and reduced their enjoyment of online learning. Several students had technological problems that made them doubt their abilities to succeed (e.g., an underpowered laptop or trouble using software or the LMS) and were uncomfortable with the amount of screen time required. 
Students developed learning strategies to overcome difficulties associated with ERT. Those who considered themselves successful set weekly goals and crossed them out upon completion [74]. Similarly, students who adjusted their working methods in the face of ERT (e.g., changing where and when they studied or taking notes differently) and proactively contacted classmates before, during, and after the live sessions felt less isolated, had more confidence in their work, and completed assignments on time or before they were due [57]. These learning strategies were directly correlated, with success, in this new mode of learning. In contrast, students who struggled with time management often fell behind and blamed the teacher or the online format for their frustration, confusion, and, sometimes, for unsatisfactory grades. These students were unable to sustain motivation and self-regulate learning [33,34].

\section{Pedagogical Implications}

The findings of this study have important pedagogical implications. Four strategies could help English learners reduce learning anxiety and foster self-regulation during ERT. First, teachers could take advantage of their LMS to make course materials and supplemental materials easily available. Second, they could take advantage of asynchronous tools on the LMS to promote social engagement (e.g., discussion forums, wikis, and blogs). Third, they could pair up students for classwork, and out-of-class assignments, to foster a sense of community. Fourth, they could encourage collaborative learning during live sessions by incorporating Zoom features such as polls, screen sharing, annotation, reactions (emojis), breakout rooms, and chats [75].

Student-response systems, such as GoSoapBox and Mentimeter, could be used to enhance the learning experience and create social engagement $[57,76,77]$. Teachers could provide pre-session, and follow-up session, emails or podcasts to remind students of weekly tasks and explain how to complete them. They could as provide feedback on assignments and homework using a screen recorder (i.e., screencast) to ensure that students feel connected to the course and teachers. These pedagogical suggestions would suppress learning anxiety and improve online learning skills in emergency remote online English learners.

This study was conducted in Hong Kong with mainland Chinese learners enrolled in a Master of Education program. The learners were culturally and linguistically homogenous, which might bias the findings. Nevertheless, the findings provide a starting point for future research; few studies have explored the role of emotions and self-regulation during ERT. Because this study was small, future researchers may consider inviting a larger number of students to participate. We only investigated students in a master's degree program. It is uncertain whether undergraduates would have similar feelings about online learning and develop comparable learning strategies. Thus, future studies should recruit both postgraduate and undergraduate students. Most importantly, more effort should be made to understand student emotions that are important in mastering self-regulated learning. Additionally, future research may consider conducting statistical analyses of the data and identifying correlations between students' use of self-regulated learning strategies and their academic performance.

Author Contributions: Conceptualization, L.K. and D.Z.; methodology, L.K. and D.Z.; formal analysis, L.K. and R.Z. writing — original draft preparation, L.K. and R.Z.; writing — review and editing, L.K., D.Z. and R.Z. All authors have read and agreed to the published version of the manuscript.

Funding: This research received no external funding.

Institutional Review Board Statement: The study was conducted according to the guidelines of the Declaration of Helsinki, and approved by the Ethics Committee of The Education University of Hong Kong (protocol code: 0360 and date of approval: 17 June 2019).

Informed Consent Statement: Informed consent was obtained from all subjects involved in the study. 
Data Availability Statement: The datasets used and/or analyzed during the current study are available from the corresponding author on reasonable request.

Conflicts of Interest: The authors declare no conflict of interest.

\section{References}

1. Ross, B.; Gage, K. Global perspectives on blended learning: Insight from WebCT and our customers in higher education. In Handbook of Blended Learning: Global Perspectives, Local Designs; Bonk, C.J., Graham, C.R., Eds.; Pfeiffer: San Francisco, CA, USA, 2006; pp. 155-168.

2. Norberg, A.; Dziuban, C.D.; Moskal, P.D. A time-based blended learning model. Horizon 2011, 19, 207-216. [CrossRef]

3. Garcia, E.; Moizer, J.; Wilkins, S.; Haddoud, M.Y. Student learning in higher education through blogging in classroom. Comput. Educ. 2019, 136, 61-74. [CrossRef]

4. Godwin-Jones, R. Emerging technologies: Mobile Apps for Language Learning. Lang. Learn. Technol. $2011,15,2-11$.

5. Luef, A.M.; Ghebru, B.; Ilon, L. Apps for language learning: Their use across different languages in a Korean context. Interact. Learn. Environ. 2018, 28, 1036-1047. [CrossRef]

6. Lai, C.; Gu, M. Self-regulated out-of-class language learning with technology. Comput. Assist. Lang. Learn. 2011, 24, 317-335. [CrossRef]

7. Lin, C.-H.; Zhang, Y.; Zheng, B. The roles of learning strategies and motivation in online language learning: A structural equation modelling analysis. Comput. Educ. 2017, 113, 75-85. [CrossRef]

8. Pekrun, R.; Elliot, A.J.; Maier, M.A. Achievement goals and achievement emotions: Testing a model of their joint relations with academic performance. J. Educ. Psychol. 2009, 101, 115-135. [CrossRef]

9. Pekrun, R.; Goetz, T.; Titz, W.; Perry, R.P. Academic emotions in students' self-regulated learning and achievement: A program of qualitative and quantitative research. Educ. Psychol. 2002, 37, 99-105. [CrossRef]

10. Schunk, D.H.; Pintrich, P.R.; Meece, J.L. Motivation in Education: Theory, Research, and Applications, 3rd ed.; Pearson Education: Upper Saddle River, NJ, USA, 2008.

11. Schutz, P.A.; Pekrun, R. Emotion in Education; Academic Press: San Diego, CA, USA, 2007.

12. Artino, A.R.; Jones, K.D. Exploring the complex relations between achievement emotions and self-regulated learning behaviours in online learning. Internet High. Educ. 2012, 15, 170-175. [CrossRef]

13. Wosnitza, M.; Volet, S. Origin, direction and impact of emotions in social online learning. Internet High. Educ. 2005, 15, 449-464. [CrossRef]

14. Zembylas, M.; Theodorou, M.; Pavlakis, A. The role of emotions in the experience of online learning: Challenges and opportunities. Educ. Media Int. 2008, 45, 107-117. [CrossRef]

15. Hodges, C.; Moore, S.; Lockee, B.; Trust, T.; Bond, A. The difference between emergency remote teaching and online learning. Educ. Rev. 2020, 27, 1-12.

16. Allen, I.E.; Seaman, J. Grade Change: Tracking Online Education in the United States; Babson Survey Research Group: Babson Park, FL, USA, 2014.

17. Khan, P.; Everington, L.; Kelm, K.; Reid, I.; Watkins, F. Understanding student engagement in online learning environments: The role of reflexivity. Educ. Technol. Res. Dev. 2017, 65, 203-218. [CrossRef]

18. Lee, K. Rethinking the accessibility of online higher education: A historical review. Internet High. Educ. 2017, 33, 15-23. [CrossRef]

19. Dirkx, J.M. The meaning and role of emotions in adult learning. New Dir. Ault. Contin. Educ. 2008, 120, 7-18. [CrossRef]

20. Lehman, R. The role of emotion in creating instructor and learner presence in the distance education experience. J. Cogn. Affect. Learn. 2006, 2, 12-26.

21. Shao, K.; Pekrun, R.; Nicholson, L. Emotions in Classroom Language Learning: What Can We Learn From Achievement Emotion Research? System 2019, 86, 102-121. [CrossRef]

22. Pekrun, R.; Elliot, A.J.; Maier, M.A. Achievement goals and discrete achievement emotions: A theoretical model and prospective test. J. Educ. Psychol. 2006, 98, 583-597. [CrossRef]

23. Pekrun, R.; von Hofe, R.; Blum, W.; Frenzel, A.C.; Goetz, T.; Wartha, S. Development of mathematical competencies in adolescence: The PALMA longitudinal study. In Studies on the Educational Quality of Schools; Prenzel, M., Ed.; Waxmann: Muenster, Germany, 2007; pp. 17-37.

24. Daniels, L.M.; Stupnisky, R.H. Not that different in theory: Discussing the control-value theory of emotions in online learning environments. Internet High. Educ. 2012, 15, 222-226. [CrossRef]

25. Pekrun, R.; Stephens, E.J. Achievement emotions: A control-value approach. Soc. Personal. Psychol. Compass 2010, 4, 238-255. [CrossRef]

26. Hara, N.; Kling, R. Communities of practice with and without information technology. In American Society of Information Science and Technology 2002: Information, Connections and Community, Philadelphia, USA, November 18-21, 2002; Rasmussen, E.M., Toms, E., Eds.; Information Today: Medford, OR, USA, 2002; Volume 39, pp. 338-349.

27. You, J.W.; Kim, H.; Park, S.H. Development and construct validation of e-learning academic emotion scale (e-AES). J. Yeolin Educ. 2012, 20, 19-44.

28. You, J.W. The structured relationship among task value, self-efficacy, goal structure, and academic emotions for promoting self-regulated learning in e-learning course. J. Korean Assoc. Comput. Educ. 2012, 16, 61-77. 
29. Dörnyei, Z. The L2 Motivational Self System. In Motivation, Language Identity and the L2 Self; Dörnyei, Z., Ushioda, E., Eds.; Multilingual Matters: Bristol, UK, 2009; pp. 9-42.

30. Freeman, D. Teaching in the context of English-language learners: What do we need to know? In Teaching Immigrant and Second Language Students; Sadowski, M., Ed.; Harvard University Press: Cambridge, MA, USA, 2004; pp. 7-20.

31. Kramsch, C.J. The Multilingual Subject; Oxford University Press: Oxford, UK, 2009.

32. Bown, J.; White, C. A social and cognitive approach to affect in SLA. Int. Rev. Appl. Linguist. Lang. Teach. 2010, 48, 331-353. [CrossRef]

33. Catterall, J.; Davis, J. Supporting new students from vocational education and training: Finding a reusable solution to address recurring learning difficulties in e-learning. Australas. J. Educ. Technol. 2013, 29, 640-650.

34. You, J.W.; Kang, M. The role of academic emotions in the relationship between perceived academic control and self-regulated learning in online learning. Comput. Educ. 2014, 77, 125-133. [CrossRef]

35. Hromalik, C.D.; Koszalka, T.A. Self-regulation of the use of digital resources in an online language learning course improves learning outcomes. Distance Educ. 2018, 39, 528-547. [CrossRef]

36. Hu, P.; Zhang, J. A pathway to learner autonomy: A self-determination theory perspective. Asia Pac. Educ. Rev. 2017, 18, 147-157. [CrossRef]

37. Zimmerman, B.J. Developing self-fulfilling cycles of academic regulation: An analysis of exemplary instructional models. In Self-Regulated Learning: From Teaching to Self-Reflective Practice; Schunk, D.H., Zimmerman, B.J., Eds.; Guilford Publications: New York, NY, USA, 1998; pp. 1-19.

38. Zimmerman, B.J.; Martinez-Pons, M. Construct validation of a strategy model of student self-regulated learning. J. Educ. Psychol. 1988, 80, 284-290. [CrossRef]

39. Pintrich, P.R.; de Groot, E.V. Motivational and self-regulated components of classroom academic performance. J. Educ. Psychol. 1990, 82, 33-40. [CrossRef]

40. Broadbent, J.; Poon, W.L. Self-regulated learning strategies \& Academic achievement in online higher education learning environments: A systematic review. Internet High. Educ. 2015, 27, 1-13.

41. Cho, M.-H.; Shen, D. Self-regulation in online learning. Distance Educ. 2013, 34, 290-301. [CrossRef]

42. Zimmerman, B.J. Investigating self-regulation and motivation: Historical backgrounds, methodological developments, and future prospects. Am. Educ. Res. J. 2008, 45, 166-183. [CrossRef]

43. Cho, M.-H.; Kim, Y.; Choi, D.H. The effect of self-regulated learning on college students' perception of community of inquiry and affective outcomes in online learning. Internet High. Educ. 2017, 24, 10-17. [CrossRef]

44. Kuo, Y.-C.; Walker, A.E.; Belland, B.R.; Schroder, K.E.E. A predictive study of student satisfaction in online education programs. Int. Rev. Res. Open Distrib. Learn. 2013, 14, 16-39. [CrossRef]

45. Yukselturk, E.; Bulut, S. Predictors for student success in an online course. Educ. Technol. Soc. 2007, 10, 71-83.

46. Oxford, R.L. Teaching and Researching Language Learning Strategies; Pearson Longman: Essex, UK, 2011.

47. Kizil, A.S.; Savran, Z. Self-regulated learning in the digital age: An EFL perspective. Res. Youth Lang. 2016, 10, 147-158.

48. Zheng, L.; Li, X.; Chen, F. Effects of a mobile self-regulated learning approach on students' learning achievement and self-regulated learning skills. Innov. Educ. Teach. Int. 2018, 55, 616-624. [CrossRef]

49. Wong, J.; Baars, M.; Davis, D.; Zee, T.V.D.; Houben, G.-J.; Paas, F. Supporting self-regulated learning in online learning environments and MOOCs: A systematic review. Int. J. Hum. Comput. Interact. 2019, 35, 356-373. [CrossRef]

50. Sahin, M.; Keskin, S.; Özgür, A.; Yurdugül, H. Determination of interaction profiles based on learner characteristics in e-learning environment. Educ. Technol. Theory Pract. 2017, 7, 172-192.

51. Weiser, O.; Blau, I.; Eshet-Alkalai, Y. How do medium naturalness, teaching-learning interactions and students' personality traits affect participation in synchronous E-learning? Internet High. Educ. 2018, 37, 40-51. [CrossRef]

52. Limperos, A.M.; Buckner, M.M.; Kaufmann, R.; Frisby, B.N. Online teaching and technological affordances: An experimental investigation into the impact of modality and clarity on perceived and actual learning. Comput. Educ. 2015, 83, 1-9. [CrossRef]

53. Richardson, J.C.; Swan, K. Examining social presence in online courses in relation to students' perceived learning and satisfaction. J. Asynchronous Learn. Netw. 2003, 7, 68-88.

54. Swan, K.; Shih, L.F. On the nature and development of social presence in online course discussions. J. Asynchronous Learn. Netw. 2005, 9, 115-136. [CrossRef]

55. Bai, J.; Li, C.; Yeh, W.C. Integrating Technology in the Teaching of Advanced Chinese. J. Technol. Chin. Lang. Teach. 2019, 10, 73-90.

56. Singh, V.; Thurman, A. How many ways can we define online learning? A systematic literature review of definitions of online learning (1988-2018). Am. J. Distance Educ. 2019, 33, 289-306. [CrossRef]

57. Kohnke, L.; Moorhouse, B.L. Adopting HyFlex in higher education in response to COVID-19: Students' perspectives. Open Learn. J. Open Distance e-Learn. 2021. [CrossRef]

58. Moorhouse, L.B.; Kohnke, L. Thriving or Surviving Emergency Remote Teaching Necessitated by COVID-19: University Teachers Perspectives. Asia Pac. Edu. Res. 2021, 30, 270-287.

59. Chen, M.P.; Wang, L.C.; Zou, D.; Lin, S.Y.; Xie, H.; Tsai, C.C. Effects of captions and English proficiency on learning effectiveness, motivation and attitude in augmented-reality-enhanced theme-based contextualized EFL learning. Comput. Assist. Lang. Learn. 2020, 1-31. [CrossRef] 
60. Ivankova, N.V.; Creswell, J.W.; Stick, S.L. Using mixed-methods sequential explanatory design: From theory to practice. Field Methods 2006, 18, 3-20. [CrossRef]

61. Creswell, J.W. Educational Research: Planning, Conducting, and Evaluating Quantitative and Qualitative Research, 3rd ed.; Pearson Education: Upper Saddle River, NJ, USA, 2008.

62. Tashakkori, A.; Teddlie, C. Applied Social Research Methods Series, Vol. 46. Mixed Methodology: Combining qualitative and quantitative approaches; Sage Publications: Thousand Oaks, CA, USA, 1998.

63. Braun, V.; Clark, V. Using thematic analysis in psychology. Qual. Res. Psychol. 2006, 3, 77-101. [CrossRef]

64. Cohen, L.; Manion, L.; Morrison, K. Research Methods in Education, 7th ed.; Routledge: London, UK, 2011.

65. Anney, V.N. Ensuring the quality of the findings of qualitative research: Looking at trustworthiness criteria. J. Emerg. Trends Educ. Res. Policy Stud. 2014, 5, 272-281.

66. Mason, J. Qualitative Researching, 2nd ed.; Sage Publications: London, UK, 2002.

67. Kaufmann, R.; Vallade, J.I. Exploring connections in the online learning environment: Student perceptions of rapport, climate, and loneliness. Interact. Learn. Environ. 2020, 1-15. [CrossRef]

68. Reio, T.G.; Crim, S.J. Social presence and student satisfaction as predictors of online enrolment intent. Am. J. Distance Educ. 2013, 27, 122-133. [CrossRef]

69. Lazarevic, B.; Bentz, D. Student perception of stress in online and face-to-face learning: The exploration of stress determinants. Am. J. Distance Educ. 2020, 35(1), 1-14. [CrossRef]

70. Abdous, M. Influence of satisfaction and preparedness on online students' feelings of anxiety. Internet High. Educ. 2019, 41, 34-44. [CrossRef]

71. Young, S.; Duncan, H.E. Online and face-to-face Teaching: How do student ratings differ? MERLOT J. Online Learn. Teach. 2014, $10,70-79$.

72. Moorhouse, B.L.; Li, Y.; Walsh, S. E-Classroom Interactional Competencies: Mediating and Assisting Language Learning During Synchronous Online Lessons. RELC J. 2021. [CrossRef]

73. Chen, L.; Chen, T.L.; Chen, N.S. Students' perspectives of using cooperative learning in a flipped statistics classroom. Australas. J. Educ. Technol. 2015, 31, 2015. [CrossRef]

74. Zheng, C.; Liang, J.C.; Li, M.; Tsai, C.C. The relationship between English language learners' motivation and online self-regulation: A structural equation modelling approach. System 2018, 76, 144-157. [CrossRef]

75. Kohnke, L.; Moorhouse, B.L. Facilitating Synchronous Online Language Learning through Zoom. RELC J. 2020. [CrossRef]

76. Kohnke, L. Tech Review: GoSoapBox-Encourage Participation and Interaction in the Language Classroom. RELC J. 2020. [CrossRef]

77. Moorhouse, B.L.; Kohnke, L. Using Mentimeter to elicit student responses in the EAP/ESP Classroom. RELC J. 2020, 51, 198-204. [CrossRef] 